\title{
How Does Investment Climate and Business Environment Impact Firms' Efficiency in a Post-Conflict Setting? Evidence from Democratic Republic of Congo
}

\author{
Edson Niyonsaba Sebigunda ${ }^{1}$ \\ ${ }^{1}$ Department of Management, University of Goma, Goma, Democratic Republic of Congo \\ Correspondence: Edson Niyonsaba Sebigunda, Centre d'Etudes et de Recherches en Economie et Gestion \\ (CEREG), Yaoundé II University, P. Box: 8309, Yaoundé, Cameroon. Tel: 237-7434-0550. E-mail: \\ nathedson@gmail.com
}

Received: November 6, 2012

Accepted: April 8, 2013 Online Published: April 27, 2013

doi:10.5539/ijbm.v8n10p169

URL: http://dx.doi.org/10.5539/ijbm.v8n10p169

\begin{abstract}
The paper explores links between business environment and firm efficiency in Democratic Republic of Congo (DRC). It builds on 105 firms from the World Bank Enterprise Survey which are observed over 2006-2010, that is the year the first democratic government was installed and five years later, at the end of the political term. The findings of the paper show that, five years after conflict in DRC, firms' efficiency rises from 0.0707 to 0.0742 over a scale spanning from 0 to 1 . The mean-comparison test indicates that firm's efficiency in DRC was not significantly improved five years after democratic election 2010. Over the same period, the Hostility Business Environment Index (HBEI) rises from 0.4914 to 0.5765 . The essential source of that variation was the deterioration of Business and government relationship. The weight in the index was $28.28 \%$ in 2006 against $57.09 \%$ in 2010 . Using Tobit regression, the study reveals a positive link between hostility business environment and firm efficiency. Quantile Regression outputs show that only firms able to pay the highest bribes, and thus, the most efficient profit from those disorders. This counter intuitive result may find an explanation for the corruption practices used by businesspeople to overcome environment constraint and inefficient barriers.
\end{abstract}

Keywords: Data Envelopment Analysis (DEA), investment climate and business environment, firm performance

\section{Introduction}

Recent research on the performance of firms across African countries points out the important role of the business environment, such as infrastructure and services constraints, sales and supplies practices, competition regulation, land and permits getting, crime, finance and labor force access, relationship between business and government, etc (Kinda, 2010; Asiedu and Freeman, 2009; Eifert et al., 2008; Fosu et al., 2001). Although prior research has identified several empirical regularities, it is based on different countries without identifying fixed effects due to the specificity of each country or a set of them. Due to differences in political stability, endowment in natural resources, institutional roles and existing business constraints, a large heterogeneity may be observed among African countries. Thus, clarifying on specific realities of each country could provide more interesting information useful to investors.

Globally, empirical research on developing economies provides two broad views on how investment climate and business environment determine firm efficiency. According to the first view, basic infrastructures and institutional constraints are presented as main obstacles to business efficiency. In this optic, Kinda (2010) shows that constraints related to investment climate hamper Foreign Direct Investment (FDI). Using firm-level data across 77 developing countries, Kinda (2010) found that physical infrastructure problems, financing constraints, and institutional problems discourage FDI. Comparing different sectors of activity and Sub-Saharan Africa to others developing countries, the study also highlights that exporter foreign firms are more constrained in their activity by physical infrastructure hurdles and the lack of skilled workers compared to firms supplying the domestic market. Firms from countries coping with civil war or violent protests are more constrained compared to others. In such countries, policies designed to attract FDI should pay particular attention to infrastructure (physical and financial) and institutions. The second group of studies underlines the strong and ambiguous effect of corruption on firms' performance (Asiedu and Freeman, 2009; Mahagaonkar, 2008; Dal Bó and Rossi, 2007; 
Emerson, 2006; Shleifer and Vishny, 1993). On this regard, corruption which is defined as "the abuse of public office for private gain", whether pecuniary or in terms of status (Note 1) consists on activities implying bribery, nepotism, theft, and other misappropriation of public resources (Bardhan, 1997, Nye, 1967; Drury et al. 2006). All these activities being of a nature to raise operational costs, corruption thus creates uncertainty and as such, it can be seen as an impediment to firms' performance (Shleifer and Vishny, 1993). However, the negative effect of corruption can be neutralized or offset in situations where corruption greases the wheels of business, e.g. creates opportunities for private illicit gains to firms, such as paying cash for contracts (Rose-Ackerman, 2002).Thus, all else equal, firms that benefit from corruption may expand their activities by increasing investments and become more efficient. This suggests that the overall theoretical impact of corruption on firm-level performance is unclear: it can be negative, positive, or neutral; depending on which of the two opposing effects dominates. Thus, the effect of corruption on firm-level efficiency is an empirical issue. Moreover, although Kinda (2010) shows how investment climate hampers FDI, it would be interesting to know how the same investment climate impact firm's performance. Our study aims at filling this gap and builds on the case of Democratic Republic of Congo (DRC), one of particular countries in Sub-Saharan area (Note 2). The main objective of the paper is to appraise the contribution of democratic institutions installed from 2006 to the improvement of business environment and consequently, to that of firm's efficiency. In others terms, at the end of the political term (in 2010), how was the evolution of business environment and to what extent did it impact the efficiency of existing firm's? Answers to those questions will provide several policies helpful for both local and foreign investors. Findings could also inspire the state in how reforms may be reinforced in order to stimulate investment.

The case of DR Congo appears very interesting on several regards. Since 1993 this country has gone through long episodes of political turmoil which seriously undermined all its institutions as well as their capacity of acting effectively in addition to billions of lives that they have claimed. From 2003 to early 2006, after the peace agreement between the government and different rebel's movements, the country experienced a political transition which resulted in mid-2006 in the organization of the first general and democratic elections. Since then, the Congolese authorities are rehabilitating and putting in place several institutions with the objective of improving the business climate of the country. However, so far little is known on the effectiveness of the different reforms that have been implemented. For instance, a recent study (Kaufmann et al., 2009) using Worldwide Governance Indicators (WGI), covering 212 countries and territories and measuring 6 dimensions of governance between 1996 and 2008 indicate that the DRC governance score in regulatory quality (Note 3), was -1.43 in 2008 against -2.43 in 1998. In spite of being a significant improvement in regulatory quality aspects, the latter governance score lies in a negative margin. Moreover, though providing interesting outcomes, the above study need needs to be complemented by a clear focus on other aspects of the business environment.

The predominant, although not exclusive, view of corruption is that it is damaging to economic performance as both a tax on productivity and a market distortion. It has shown that corruption has a negative and significant impact on growth, investment, capital flows, innovation, entrepreneurship performance (Mauro, 1995; Brunetti and Weder, 2003, Doh and Teegen, 2003) and competition (Emerson, 2006). Our focus in this paper is on one of the most pervasive channels through which corruption is known to work, namely the costs of doing business. As stated above, there exist several studies evaluating the impact of investment climate and business environment on firm's performance. Most of them show that the deterioration of business environment has a negative and significant effect on firms' performance. However, to our knowledge, the impact of investment climate and business environment on firms' efficiency in a post-conflict environment has not been yet clarified.

Thus, the present study aims at verifying the following assumption in Democratic Republic of Congo (DRC) context:

- $\quad \mathrm{H}_{1}$ : the deterioration of business environment has a negative and significant effect on firms' performance;

- $\mathrm{H}_{2}$ : even if it appears as a rational behavior in a constrained environment, corruption has a negative and significant effect on firms' performance.

The contribution of this paper is thus threefold. First, the study pays attention on how investment climate and business environment were improved in a post-conflict setting. Secondly, firms' efficiency is measured and compared over 2006 and 2010 (period of the first political term after conflicts) through a robust methodology allowing to aggregate different dimensions of governance indicators based on principal component analysis. Finally, for both periods, interaction between variation of the hostility business environment and firms' efficiency is evaluated. 


\section{Research Design}

\subsection{Efficiency Measurement}

This paper uses Data Envelopment Analysis (DEA), a non-parametric approach, to estimate a production function in order to assess efficiency in firms. Since DEA was first introduced by Charnes, Cooper, and Rhodes in 1978, the simple yet powerful method has been vastly developed and used to assess the relative efficiencies of a decision making unit (DMU). The popularity of DEA is due to its ability to measure relative efficiencies of multiple input and multiple-output DMUs without prior weights on the inputs and outputs. To date, DEA is still widely researched and is being applied as internal/external benchmarking tools in many areas and domains. Such as in banking industry (Camanho and Dyson, 2005), information technology and information system (Azadeh, et al., 2009), education (Agasisti and Pérez-Esparrells, 2010), airline (Yu and Chen, 2009), computer industry (Chen and Iqbal Ali, 2004), power plant (Cook and Zhu, 2007), sport (Cooper et al., 2009), stock market (Deetz et al., 2009), government (Wang et al. 2009), supply chain (Wong and Wong, 2007), and many more. Readers should be noted that the coverage of this paper is not meant to be complete as the volume of literature is immense. Readers who are interested in a thorough discussion on the various topics of DEA are advised to refer to a thorough literature review on DEA by Cook and Seiford (Cook and Seiford, 2009) and Kuah, Wong, and Behrouzi (2010).

In this study, DEA is used to assess the relative efficiency of the firms and explores the contribution of inputs and outputs to technical efficiency by utilizing the efficiency decomposition. Each firm is treated as a DMU. As implied in Cooper et al. (2001), the number of carriers should be at least triple the number of inputs and outputs considered. Here the data set consists of four-inputs and two-output and the number of companies is 105 , which is more than three times larger the combined inputs and outputs. All variables used in efficiency measurement (inputs and outputs) are taken from the World Bank Enterprise Surveys data base. The description of input and output variables are:

\subsubsection{Input Variables}

(1) Amount of total annual cost of labor including wages, salaries, bonuses, social security payments in local currency;

(2) Amount of total annual cost of raw materials and intermediate goods used in production in local current;

(3) Amount of total annual costs of fuel and electricity in local current;

(4) Amount of other cost of production not included above (annual depreciation costs, etc.) in local current.

\subsubsection{Output Variables}

(1) Amount of total annual sales in local current;

(2) Increase (decrease) in permanent full-time workers on tree last years. This variable is measured by the difference between the number of full-time employees in 2010 and the number of full-time employees in the establishment three fiscal years ago.

DEA measures the relative efficiency of organizations (firms in our case) and can handle multiple inputs and outputs. Relative efficiency is defined as the ratio of weighted output to weighted input. By comparing $\mathrm{n}$ organizations with $p$ outputs denoted by $y_{r 0}, r=1, \ldots, p$ and $q$ inputs denoted by $x_{i 0}, i=1, \ldots, q$, the efficiency of an organization $(0=1, \ldots, n)$ can be computed as a solution to linear program:

$$
\left\{\begin{array}{l}
h_{o}=\operatorname{Max} \sum_{r=1}^{p} u_{r} y_{r 0} \\
\text { s.t } \\
\sum_{i=1}^{q} v_{i} x_{i o}=1 \\
\sum_{r=1}^{p} u_{r} y_{r j}-\sum_{i=1}^{q} v_{i} x_{i j} \leq 0, j=1, \ldots, n, \\
u_{i}, v_{i} \geq \varepsilon>0 ; i=1, \ldots, q ; r=1, \ldots, p .
\end{array}\right.
$$

The weights $u_{r}$ and $v_{i}$ are non-negative. The constraint requires that the weights do not allow the efficiency of a firm to exceed one. The efficiency score, $h_{o}$, ranges from zero to one; if a $D M U_{o}$ receives a score of unity it 
will be considered relatively efficient. Therefore, each firm will choose weights so as to maximize internal-efficiency, given the constraints. Carriers are deemed efficient if they lie on the outer envelope, otherwise they are deemed inefficient. Equation (1) is often referred to as the Charnes, Cooper, and Rhodes (CCR) model (Charnes et al., 1978) and assumes that the production function exhibits constant returns to scale (CRS). $\left(v_{i}^{*}, u_{i}^{*}\right)$ is the set of most favorable weights for an airline to maximize the ratio scale; $v_{i}^{*}$ is the optimal weight for an input item and its size is an indicator of how highly the item is evaluated. Similarly, $u_{i}^{*}$ does the same for the output item. In addition, if we examine each item $v_{i}^{*} x_{i o}$ in the virtual input

$$
\sum_{i=1}^{q} v_{i}^{*} x_{i o}(=1)
$$

We can reference the value of each $v_{i}^{*} x_{i o}$ to understand the relative importance of items. The same holds for $u_{r}^{*} y_{i o}$ where the $u_{r}^{*}$ gives a measure of the relative contribution of $y_{i o}$ to the overall value of $h^{*}$.

After having evaluated firms' efficiency, the mean-comparison test will be used to explain the difference in outcome between firms' efficiency observed in the two wives (2006 and 2010). The same test will permit us to evaluate the difference in firms' efficiency due to corruption practices through the two wives of samples.

\subsection{Hostility Business Environment Index Computation}

Hostility business environment is reflected in the social, political and economic markets and in infrastructural resources (Specht, 1993). Edelstein (1992) mentions that a hostile environment is one in which the changes in the external environment of the firm are perceived as unfavorable to the mission or outputs of the firm. This environment can be characterized, for example by tough competition in the market, low margins, oppressive governmental regulations and limited growth opportunities (Zahra et al., 1997). Environmental hostility is regarded as one of the most important attributes for explaining strategic behaviours and outcomes (Elbanna, 2009). Although there is little empirical research examining the impact of environmental hostility on organizational strategy, structures, innovation decision-making and organizational outcomes, previous research clearly points to its importance (Elbanna, 2009; Goll \& Rasheed, 1997; Kotha \& Nair, 1995; Wan \& Hoskisson, 2003). For example, Rajagopalan et al. (1993) argue that organizations in munificent environments are less likely to be penalised for poor decisions than those in hostile environments; thus, decision processes which are suited to munificent environments may be inappropriate for less munificent ones. Elbanna and Child (2007) and McArthur and Nystrom (1991) demonstrate that the level of environmental hostility-munificence was a significant predictor of the relationship between the strategy process and organizational outcomes. Miller and Friesen (1983) report a positive relationship between environmental hostility and the degree of analysis in the strategy process. The literature assumes that organizations facing high uncertainty and hostility in the environment will tend to be more market oriented (Lonial and Raju, 2001) to ease the negative influence on performance. Baum and Wally (2003) report that high environmental munificence positively relates to organizational performance in terms of growth and profitability. Therefore, to clarify this issue practically within the DRC context, we used a composite index to aggregate several environment indicators. Using an index, it is easier to analyze business environment dynamic and relate it to performance indicator. This is an advance on previous studies such us Morgan et al. (1993) and Jeffrey and Michael (1997).

Sixteen (16) indicators summarized in eight (8) dimensions are used to construct the Hostility Business Environment Index (HBEI). All variables are selected from the World Bank Enterprise Survey (WBES) as followed:

- Infrastructure and services: as one of business environment constraint in developing countries and in DRC specially, this dimension takes into electricity (access, outages, cost...) and telecommunications aspects as viewed by firms' managers;

- Sales and supplies: sales and supplies constraints summarize transport problems, customs and trade regulations. The main idea is to know how and where the establishment makes its sales;

- Competition: this aspect of doing business constraints is interested in practices of competitors in the informal sector again the considered enterprise;

- $\quad$ Land and permits: this dimension permits to evaluate how depth are access to land and getting permits problems in current operations of the establishment;

- Crime: this dimension evaluates the severity of crime, theft and disorder in different obstacles to the current operations of this establishment. This aspect is more important in a post conflict setting like DRC; 
- Finance: here the question is at which level access to finance, which includes availability and cost, interest rates, fees and collateral requirements contribute to the hostility of doing business environment;

- Business-government Relationship: mains problems between business and government concern tax rates, tax administration, business licensing and permits, political instability, corruption and Courts;

- Labor: how deep labor regulations and educated workforce inadequacy are in doing business constraints?

All theses constraints are quantified on an ordinal scale. If an issue poses a problem, the manager had to judge its severity as an obstacle on a four-point scale where: $0=$ no obstacle $1=$ minor obstacle $2=$ moderate obstacle $3=$ major obstacle $4=$ very severe obstacle.

Using Nagar and Basu (2002) indexation methodology, the eight dimensions are aggregated in a Hostility Business Environment Index (HBEI). This methodology is based on principal component (PCA) analyze and is adapted to discrete variables (PCA-Polychoric) as suggested by Kolenikov and Angeles (2004) .

Thus, we transform the causal variables into their standardized form through equation (3), where $\bar{x}_{k}$ is the arithmetic mean and $s_{x k}$ is the standard deviation of observations on $x_{k}$.

$$
X_{k}=\frac{x_{k}-\bar{x}_{k}}{s_{x k}}
$$

The covariance matrix of the standardized variables is, in fact, the correlation matrix $R$ adapted to discrete of the indicator variables (Kolenikov and Angeles, 2004).

Let $\lambda_{1}>\lambda_{2}>\cdots>\lambda_{K}$ be the eigen values of $R$ in descending order of magnitude, and the corresponding eigen vectors be:

$$
\alpha_{1}=\left(\begin{array}{c}
\alpha_{11} \\
\vdots \\
\vdots \\
\alpha_{1 K}
\end{array}\right), \ldots,\left(\begin{array}{c}
\alpha_{K 1} \\
\vdots \\
\alpha_{K K}
\end{array}\right) \text {, such that } \alpha_{i} \alpha_{i}^{\prime}=1 \text { and } \alpha_{i} \alpha_{j}^{\prime}=0 \text { for } i \neq j=1, \ldots, K
$$

Then, the successive principal components are:

$$
\left\{\begin{array}{l}
P_{1}=\alpha_{11} x_{1}+\cdots+\alpha_{1 K} x_{K} \\
P_{K}=\alpha_{K 1} x_{1}+\cdots+\alpha_{K K} x_{K}, \text { with } \operatorname{var} P_{i}=\lambda_{i} \text { for } i=1, \ldots, K
\end{array}\right.
$$

We define the Hostility Business Environment Index (HBEI) as a weighted average of successive principal components as:

$$
H B E I=\frac{\lambda_{1} P C_{1}+\cdots+\lambda_{k} P C_{k}}{\lambda_{1}+\cdots+\lambda_{k}} \Rightarrow H B E I=\frac{\sum \lambda_{k} \alpha_{k 1}}{\lambda_{k}} x_{1}+\cdots+\frac{\sum \lambda_{k} \alpha_{k k}}{\lambda_{k}} x_{k}
$$

Finally, the Hostility Business Environment Index (HBEI) computed is reduced to scale which fluctuate from 0 to 1 using the (5) equation.

$$
H B E I=\frac{H B E I_{i}-\min (H B E I)}{\max (H B E I)-\min (H B E I)}
$$

Including all $K$ principal components in the index is advantageous (Krishnakumar and Nagar, 2008; Nagar and Basu, 2002). In fact, the index accounts for total variation in all indicator variables. In addition, the obtained index can easily be expressed in different indicator variables. This last advantage allows us to quantify the weight of each business environment indicator in the index with a positive or a negative contribution. By so doing, the methodological tool used permits to go far than a simple principal components analysis.

\subsection{Impact of Hostility Business Environment on Firms' Efficiency: Methodological Tools}

The prevalent method in the literature to find the determinants of efficiency gaps among DMUs is by using Tobit regression analysis because the efficiency scores are censored at the maximum value of the efficiency scores ( $\mathrm{Ji}$ and Lee, 2010, Cook and Seiford, 2009, Skeels and Vella, 1997). Thus, we adopted the approach of Simar and Wilson (2007) to examine the exogenous factors, Hostility Business Environment Index and others control variables that affect firm efficiency scores.

$$
E S_{i}=\alpha+\omega H B E I_{i}+\beta Z_{i}+\varepsilon_{i}, i=1, \cdots, n
$$

Where $\varepsilon_{i} \sim N\left(0, \sigma_{\varepsilon}^{2}\right)$, such that $\varepsilon_{i} \geq 1-\alpha-\left(\omega H B E I_{i}+\beta Z_{i}\right), i==1, \cdots, n . \quad \alpha$ is the intercept, $\varepsilon_{i}$ is the residual value, $H B E I_{i}$ is the Hostility Business Environment Index, and $Z_{i}$ others control variables (corruption 
practices, firms' size, firms' age, activities sector and firms' geographic localization) that we expected is related to the firms' efficiency score measured by $E S_{i}$. This analysis is completed by quantiles regression (Koenker and Hallock, 2001). The purpose is to evaluate the effect of the HBEI on different levels of firms' efficiency. The robustness of the model is checked by using interquantiles regression in the place of quantiles regression. All analyses are made by STATA 12.0 software.

\subsection{Data, Sample Group and Descriptive Statistics}

Data used in the sample come from the World Bank Enterprise Surveys (Note 4) available for Congo D.R. Two surveys were done, one in 2006 and other, five years later in 2010. The last wave (2010) was stretched on 464 firms against 445 in the first (2006). 340 firms of the first wave are not observed in the second wave and 359 of the new wave (2010) were not observed in 2006. In the aim of to make comparison, only 105 firms founded in both of the two waves are here analyzed. This permits us to see haw performance indicator changed between the two waves inside the same firm. Manufacturing sector represents $54.29 \%$ of the final sample (105 firms) against $17.14 \%$ in retail sector, and $28.57 \%$ for other Services. Small enterprises (between 5 and 19 employees) represent $68.57 \%$ of the sample and medium (between 20 and 99 employees) and large (equal and more than 100 employees) enterprises, respectively $26.67 \%$ and $4.76 \%$. Geographically, the same simple is distributed as followed: 79.05\% in Kinshasa, 7.14\% in Matadi, 7.14\% in Lubumbashi and 6.67\% in Kisangani.

Table 1 summarizes descriptive statistics of different variables used in our econometrics analyses. We present indicators used to compute HBEI and others efficiency's determinants.

Table 1. Descriptive statistic

\begin{tabular}{lccccc}
\hline & Obs. & Mean & Std. Dev. & Min & Max \\
\hline Hostility Business Environment Index (HBEI) components & & & & & \\
Electricity (access, outages, cost,...) & 210 & 2.7762 & 1.4218 & 0 & 4 \\
Telecommunications & 210 & 0.8667 & 1.1202 & 0 & 4 \\
Transport & 210 & 1.8286 & 1.3085 & 0 & 4 \\
Customs and trade regulations & 210 & 1.7571 & 1.4781 & 0 & 4 \\
Practices of competitors in the informal sector & 210 & 2.3905 & 1.3124 & 0 & 4 \\
Access to land & 210 & 1.5048 & 1.4319 & 0 & 4 \\
Crime, thelt and disorder & 210 & 1.8952 & 1.5150 & 0 & 4 \\
Access to finance & 210 & 2.6286 & 1.3288 & 0 & 4 \\
Tax rates & 210 & 2.3190 & 1.3477 & 0 & 4 \\
Tax administration & 210 & 2.2619 & 1.3879 & 0 & 4 \\
Business licensing and permits & 210 & 1.5857 & 1.2922 & 0 & 4 \\
Political Instability & 210 & 2.5476 & 1.2904 & 0 & 4 \\
Corruption & 210 & 1.9905 & 1.5436 & 0 & 4 \\
Courts & 210 & 1.5238 & 1.3806 & 0 & 4 \\
Labor regulation & 210 & 1.2952 & 1.1527 & 0 & 4 \\
Inadequately educated workforce & 210 & 1.6190 & 1.4168 & 0 & 4 \\
Others variables & & & & & \\
Firm Efficiency & 210 & 0.0725 & 0.1739 & 0.0000 & 1 \\
Hostility Business Environment Index (HBEI) & 210 & 0.5340 & 0.2245 & 0 & 1 \\
Bribes payment \% in total of sales & 210 & 3.5000 & 6.8324 & 0 & 75 \\
Corruption practices (dummy variable) & 210 & 0.5048 & 0.5012 & 0 & 1 \\
\hline
\end{tabular}

Computed by author from World Bank Enterprise Surveys. 


\section{Business Environment and Firms' Efficiency in DRC: Empirical Evidence}

After computing firms' inputs and outputs with STATA 12 software, we compare the firm efficiency levels by period (2006 and 2010) and by corruption practices. Secondly, the Hostility Business Environment Index (HBEI) is computed and the weight of each business environment indicator in the index quantified. Finally, the impact of HBEI on firms' efficiency is measured.

3.1 Firms' Efficiency Dynamic in Democratic Republic of Congo: What Has Been Changed Five Years after New Democratic Institutions?

After evaluating the firms' efficiency by Data Envelope Analysis (DEA) method, this section present its decomposition (by period and corruption practices) using mean-comparison test tool.

Table 2. Mean-comparison test of firms' efficiency

\begin{tabular}{lccccc}
\hline & Obs. & Efficiency Mean & Std.Err. & $\boldsymbol{P r}(\boldsymbol{T}>t)$ & Evidence for Ho \\
\hline Test by period $(2006$ \& 2010$)$ & : diff $=$ mean (2006) & mean $(2010)$ & & \\
\hline 2006 & 105 & 0.0707 & $0.014(0.142)$ & & \\
2010 & 105 & 0.0742 & $0.020(0.201)$ & 0.8824 & Ho accepted \\
Combined & 210 & 0.0725 & $0.012(0.174)$ & & \\
Difference & & -0.0036 & 0.024 & & \\
\hline
\end{tabular}

Test by corruption practices for 2006 ( $1=$ if bribes are paid to overcome constraint \& $0=$ if not $):$ diff $=$ mean $(0)-\operatorname{mean}(1)$

\begin{tabular}{lccccc}
\hline 0 & 44 & 0.1040 & $0.031(0.208)$ & & \\
1 & 61 & 0.0467 & $0.007(0.051)$ & 0.0410 & Ho rejected \\
Combined & 105 & 0.0707 & $0.014(0.142)$ & & \\
Difference & & 0.0573 & 0.028 & & \\
\hline
\end{tabular}

Test by corruption practices for 2010 ( $1=$ if bribes are paid to overcome constraint \& $0=$ if not) : diff $=$ mean $(0)-\operatorname{mean}(1)$

\begin{tabular}{lccccc}
\hline 0 & 44 & 0.1040 & $0.031(0.208)$ & & \\
1 & 61 & 0.0467 & $0.007(0.051)$ & 0.0410 & Ho rejected \\
Combined & 105 & 0.0707 & $0.014(0.142)$ & & \\
Difference & & 0.0573 & 0.028 & & \\
\hline
\end{tabular}

Legend: the test provides evidence of $H o:$ diff $=0$ against Ha: diff $\neq 0$ between the two groups considered.

(...): Std.Dev. Computed by author from World Bank Enterprise Surveys.

The test's results indicate that firm efficiency in DRC wasn't significantly improved five years after democratic election (2006-2010). Five years after conflict in DRC, firms' efficiency rises from 0.0707 to 0.0742 over a scale spanning from 0 to 1 . Analyses indicate that the variation (-0.0039) isn't statistically significant.

The decomposition of efficiency level by corruption practices reveals an interesting result: contrary to the beginning situation of democratic institutions in DRC (2006), five years after at the end of political term (2010), corrupt firms realized higher efficiency levels than those not corrupt. These results match Leff (2002) and Riley (2002) conclusions. Leff (2002) found that corruption brings an element of competition with its attendant pressure for efficiency to an underdeveloped economy. By allocating contracts to the highest bidder, it ensures only those able to pay the highest bribes, and thus the most efficient (because they have to muster capital required) survive. Riley (2002) makes similar conclusions in a study of the impact of corruption in developing countries that corruption simply reflects misadministration of government in general; a way to get around inefficient and cumbersome government bureaucracies. It is suggested that bribery can be an efficient way of negotiating otherwise over regulated, cumbersome and ineffective legal systems.

3.2 Business Environment Dynamic in DRC: Did Democratization Facilitate Doing Business?

In the table 3, we present the dynamic of business constraints weight in the Hostility Business Environment Index 
(HBEI) from 2006 to 2010.

Table 3. The weight of obstacles to business doing in the Hostility Business Environment Index (HBEI)

\begin{tabular}{|c|c|c|c|c|c|c|}
\hline \multirow{2}{*}{ Dimension } & \multicolumn{2}{|c|}{ Hostility Business Environment Indicators } & \multicolumn{2}{|c|}{ weight_2006 } & \multicolumn{2}{|c|}{ weight_2010 } \\
\hline & Code & Obstacles to business operations & Indicator & Dimension & Indicator & Dimension \\
\hline Infrastructure & $\mathrm{C} 1$ & Electricity (access, outages, cost,...) & 0.0507 & \multirow{2}{*}{0.1464} & 0.0785 & \multirow{2}{*}{0.1820} \\
\hline and services & $\mathrm{C} 2$ & Telecommunications & 0.0957 & & 0.1035 & \\
\hline Sales and & $\mathrm{C} 3$ & Transport & 0.0727 & \multirow{2}{*}{0.1346} & 0.0351 & \multirow{2}{*}{0.0891} \\
\hline supplies & $\mathrm{C} 4$ & Customs and trade regulations & 0.0620 & & 0.0540 & \\
\hline Competition & $\mathrm{C} 5$ & $\begin{array}{l}\text { Practices of competitors in the informal } \\
\text { sector }\end{array}$ & 0.0906 & 0.0906 & 0.0242 & 0.0242 \\
\hline $\begin{array}{l}\text { Land and } \\
\text { permits }\end{array}$ & $\mathrm{C} 6$ & Access to land & 0.0556 & 0.0556 & 0.0410 & 0.0410 \\
\hline Crime & $\mathrm{C} 7$ & Crime, thelt and disorder & 0.0676 & 0.0676 & -0.0005 & -0.0005 \\
\hline Finance & $\mathrm{C} 8$ & Access to finance & 0.0901 & 0.0901 & 0.0273 & 0.0273 \\
\hline \multirow{6}{*}{$\begin{array}{l}\text { Business-gove } \\
\text { rnment } \\
\text { Relationship }\end{array}$} & C9 & Tax rates & 0.0142 & \multirow{6}{*}{0.2828} & 0.1222 & \multirow{6}{*}{0.5709} \\
\hline & $\mathrm{C} 10$ & Tax administration & 0.0292 & & 0.0832 & \\
\hline & $\mathrm{C} 11$ & Business licensing and permits & 0.0866 & & 0.0545 & \\
\hline & $\mathrm{C} 12$ & Political Instability & 0.0469 & & 0.1040 & \\
\hline & $\mathrm{C} 13$ & Corruption & 0.0434 & & 0.1038 & \\
\hline & $\mathrm{C} 14$ & Courts & 0.0625 & & 0.1033 & \\
\hline \multirow{2}{*}{ Labor } & $\mathrm{C} 15$ & Labor regulation & 0.0508 & \multirow{2}{*}{0.1322} & 0.0522 & \multirow{2}{*}{0.0661} \\
\hline & $\mathrm{C} 16$ & Inadequately educated workforce & 0.0813 & & 0.0139 & \\
\hline Total & & & \multicolumn{2}{|c|}{$100 \%$} & \multicolumn{2}{|c|}{$100 \%$} \\
\hline HBEI_Mean & & & \multicolumn{2}{|c|}{0.4914} & \multicolumn{2}{|c|}{0.5765} \\
\hline HBEI_Sdt.Err. & & & \multicolumn{2}{|c|}{0.2351} & \multicolumn{2}{|c|}{0.2068} \\
\hline
\end{tabular}

Computed by author from World Bank Enterprise Surveys.

Analyses made in table 3 indicate that the business environment was deteriorated from 2006 to 2010.

In others terms, the democratization didn't lead to the improvement of the investment climate in DRC as the Hostility Business Environment Index (HBEI) rose from 0.4914 to 0.5765 . The investment climate was deteriorated. The essential source of that variation was the complexity of Business and government relationship. Their weight in the index was $28.28 \%$ in 2006 against $57.09 \%$ in 2010 . Generally, others obstacles decreased in weight for the same period, except infrastructures and services dimension which increased from $14.64 \%$ in 2006 to $18.20 \%$ in 2010 . The following section aims to quantify the impact of this business environment deterioration on firms' efficiency.

\subsection{The Effect of Hostility of Business Environment on Firms' Efficiency in DRC}

First, we explain the firms' efficiency with Hostility Business Environment Index (HBEI), size, age and region of firm implantation. The strange impact of HBEI on efficiency brought us to control the model with the dummy variable relative to corruption practices. Outcomes of preliminary tests (collinearity detection, normality, Heteroskedasticity and omitted variables test) are provided in appendix 1, 2, 3 and 4 . Their discussion allowed us to run robust retrogression. The table 4 summarizes the main findings. 
Table 4. Determinants of firm' efficiency (marginal effects from Tobit regression)

\begin{tabular}{|c|c|c|c|c|}
\hline \multirow{2}{*}{ Dependent Variable: Efficiency } & \multicolumn{2}{|c|}{ Model (1) } & \multicolumn{2}{|c|}{ Model (2) } \\
\hline & 2006 & 2010 & 2006 & 2010 \\
\hline \multirow{2}{*}{ Hostility Business Environment Index (HBEI) } & $0.115^{*}$ & $0.211^{* *}$ & $0.107 *$ & $0.209 * *$ \\
\hline & $(1.85)$ & $(2.17)$ & $(1.75)$ & $(2.14)$ \\
\hline \multirow{2}{*}{ Dummy Corruption } & & & $-0.058 * *$ & 0.008 \\
\hline & & & $(2.16)$ & $(0.19)$ \\
\hline \multirow{2}{*}{ Ln(Number of employees) } & -0.016 & 0.023 & -0.014 & 0.024 \\
\hline & $(0.98)$ & $(1.08)$ & $(0.92)$ & $(1.10)$ \\
\hline \multirow{2}{*}{ Ln(Firm age) } & $-0.106 * * *$ & 0.018 & $-0.105 * * *$ & 0.018 \\
\hline & $(4.26)$ & $(0.53)$ & $(4.32)$ & $(0.52)$ \\
\hline \multirow{2}{*}{ Dummy Manufacturing } & $-0.061 *$ & $-0.090 * *$ & $-0.068 * *$ & $-0.090 * *$ \\
\hline & $(1.93)$ & $(2.08)$ & $(2.18)$ & $(2.07)$ \\
\hline \multirow{2}{*}{ Dummy Retail } & 0.005 & -0.072 & -0.004 & -0.071 \\
\hline & $(0.13)$ & $(1.25)$ & $(0.11)$ & $(1.22)$ \\
\hline Dummy Services & ref. & ref. & ref. & ref. \\
\hline \multirow{2}{*}{ Region $\sim$ Lubumbashi } & 0.023 & 0.016 & 0.044 & 0.018 \\
\hline & $(0.43)$ & $(0.20)$ & $(0.83)$ & $(0.22)$ \\
\hline \multirow{2}{*}{ Region $\sim$ Kisangani } & -0.030 & 0.109 & -0.028 & 0.110 \\
\hline & $(0.58)$ & $(1.41)$ & $(0.56)$ & $(1.41)$ \\
\hline \multirow{2}{*}{ Region $\sim$ Matadi } & -0.002 & -0.039 & -0.034 & -0.036 \\
\hline & $(0.04)$ & $(0.52)$ & $(0.65)$ & $(0.46)$ \\
\hline \multirow[t]{2}{*}{ Region Kinshasa } & ref. & ref. & ref. & ref. \\
\hline & $0.378 * * *$ & -0.100 & $0.417 * * *$ & -0.104 \\
\hline _cons & $(4.67)$ & $(0.89)$ & $(5.13)$ & $(0.91)$ \\
\hline \multirow{2}{*}{ /sigma } & $0.127 * * *$ & $0.194 * * *$ & $0.125 * * *$ & $0.194 * * *$ \\
\hline & $(14.22)$ & $(14.10)$ & $(14.23)$ & $(14.10)$ \\
\hline Obs. & 105 & 105 & 105 & 105 \\
\hline Right-censored " $n$ " at Efficiency $\geq 1$ & 2 & 3 & 2 & 3 \\
\hline$L l$ & 61.48 & 16.52 & 63.75 & 16.54 \\
\hline LR Chi (2) & 25.64 & 12.36 & 30.19 & 12.39 \\
\hline Prob $>$ chi 2 & 0.0012 & 0.1359 & 0.0004 & 0.1920 \\
\hline AIC & -102.9548 & -13.04905 & -105.5056 & -11.08603 \\
\hline$B I C$ & -76.41521 & 13.49055 & -76.31202 & 18.10753 \\
\hline Efficiency Predicted & 0.0711 & 0.07554 & 0.0710 & 0.0754 \\
\hline
\end{tabular}

Numbers in parentheses are standard deviation and $* p<0.1 ; * * p<0.05 ; * * * p<0.01$

Computed by author from World Bank Enterprise Surveys.

The results indicate that the hostility business environment index (HBEI) has positive impact on efficiency in DRC for the two waves of surveys (2006 \& 2010). The Analysis also reveals that marginal effect amplitude of "HBEI" doubled from 2006 to 2010 for the two models $(1 \& 2)$. These results indicate that five years after the democratic elections in RDC, the bad investment climate benefit more the businessmen than before.

After having controlled the model by introducing practice of corruption as a dummy variable, we realize that these results remain the same. However, we notice that the "corruption" variable has a negative effect on firms' 
efficiency in 2006, but paradoxically, the effect becomes positive (even the marginal effect is not statistically significant) in 2010 at the end of the political mandate. These conclusions are in accordance with those obtained previously by computing the HBEI. Indeed, during our recent investigation (2011), businesspeople admitted that they make money based on the public administration's disorders. These disorders encourage the development of informal practices such as contact with high political leaders. Corruption becomes an important mechanism used to overcome different barriers. In presence of these practices, fiscal charges supported by businessmen are less than these planned officially. In reality, the state is the first loser, because of the disorders are caused by the government.

Business environment hostility leads many firms to use corruption practices in order to survive in a constraining environment. In this view, the corruption practices appear as a rational behavior leading to better level of efficiency. This result meets previous studies which present corruption as a performance factor. Thus, effectives policies implemented to fight against corruption practices in DRC would pass by improvement of business environment. Indeed, the companies more affected by hostility of business environment are also the ones more implicated in corruption practices.

Even if the previous analyses showed that the hostility of business environment has a positive impact on firm efficiency, it is necessary to determine which companies are able to take advantage of this situation or not. So, we need to divide the simple in small homogenous groups and look over the previous findings. The outcomes of quantiles regression below (tables 5 and 6) will allow us to answer this question. The different quantiles (Q.10; Q.20; Q.30 and Q.95) were defined in reference to the form of the dependant variable distribution (firm efficiency).

Table 5. Firms' efficiency determinants (marginal effects from Quantile regression)

\begin{tabular}{|c|c|c|c|c|c|c|c|c|}
\hline \multirow{2}{*}{$\begin{array}{l}\text { Explained Variable: } \\
\text { Efficiency }\end{array}$} & \multicolumn{2}{|c|}{$\tau=0.10$} & \multicolumn{2}{|c|}{$\tau=0.20$} & \multicolumn{2}{|c|}{$\tau=0.30$} & \multicolumn{2}{|c|}{$\tau=0.95$} \\
\hline & 2006 & 2010 & 2006 & 2010 & 2006 & 2010 & 2006 & 2010 \\
\hline Hostility Business & -0.001 & -0.000 & 0.003 & -0.001 & 0.002 & -0.001 & $0.102 * * *$ & 0.242 \\
\hline Environment Index (HBEI) & $(0.007)$ & $(0.001)$ & $(0.009)$ & $(0.001)$ & $(0.010)$ & $(0.002)$ & $(0.015)$ & $(0.397)$ \\
\hline Dummy Corruption & $\begin{array}{l}-0.002 \\
(0.003)\end{array}$ & $\begin{array}{c}0.000 \\
(0.000)\end{array}$ & $\begin{array}{l}-0.001 \\
(0.004)\end{array}$ & $\begin{array}{c}0.000 \\
(0.000)\end{array}$ & $\begin{array}{l}-0.007 \\
(0.005)\end{array}$ & $\begin{array}{c}0.000 \\
(0.001)\end{array}$ & $\begin{array}{c}-0.760^{* * *} \\
(0.013)\end{array}$ & $\begin{array}{c}* 0.120 \\
(0.208)\end{array}$ \\
\hline Ln(Number of employees) & $\begin{array}{c}-0.005^{* * *} \\
(0.001)\end{array}$ & $\begin{array}{c}0.000 \\
(0.000)\end{array}$ & $\begin{array}{c}-0.007 * * * \\
(0.002)\end{array}$ & $\begin{array}{l}0.000 \\
(0.000)\end{array}$ & $\begin{array}{c}-0.007 * * * \\
(0.002)\end{array}$ & $\begin{array}{c}0.000 \\
(0.000)\end{array}$ & $\begin{array}{c}-0.018^{* * *} \\
(0.006)\end{array}$ & $\begin{array}{c}0.071 \\
(0.080)\end{array}$ \\
\hline Ln(Firm age) & $\begin{array}{l}-0.004 * \\
(0.002)\end{array}$ & $\begin{array}{l}-0.000 \\
(0.000)\end{array}$ & $\begin{array}{c}-0.010^{* * *} \\
(0.003)\end{array}$ & $\begin{array}{l}-0.000 \\
(0.000)\end{array}$ & $\begin{array}{c}-0.011 * * * \\
(0.003)\end{array}$ & $\begin{array}{l}-0.001 \\
(0.001)\end{array}$ & $\begin{array}{c}-0.092 * * * \\
(0.023)\end{array}$ & $\begin{array}{r}* 0.271^{* * *} \\
(0.089)\end{array}$ \\
\hline Dummy Manufacturing & $\begin{array}{l}-0.003 \\
(0.004)\end{array}$ & $\begin{array}{l}-0.001 * \\
(0.000)\end{array}$ & $\begin{array}{l}-0.002 \\
(0.005)\end{array}$ & $\begin{array}{c}-0.001 * * * \\
(0.000)\end{array}$ & $\begin{array}{l}-0.001 \\
(0.005)\end{array}$ & $\begin{array}{l}-0.001 \\
(0.001)\end{array}$ & $\begin{array}{c}-0.065^{* * *} \\
(0.019)\end{array}$ & $\begin{array}{l}*-0.160 \\
(0.246)\end{array}$ \\
\hline Dummy Retail & $\begin{array}{l}-0.005 \\
(0.004)\end{array}$ & $\begin{array}{l}-0.001 \\
(0.000)\end{array}$ & $\begin{array}{c}0.001 \\
(0.006)\end{array}$ & $\begin{array}{c}0.001 \\
(0.001)\end{array}$ & $\begin{array}{c}0.007 \\
(0.006)\end{array}$ & $\begin{array}{c}0.003 * * * \\
(0.001)\end{array}$ & $\begin{array}{c}0.011 \\
(0.011)\end{array}$ & $\begin{array}{c}-0.316^{* *} \\
(0.145)\end{array}$ \\
\hline Dummy Services & ref. & ref. & ref. & ref. & ref. & ref. & ref. & ref. \\
\hline Region Lubumbashi & $\begin{array}{l}-0.004 \\
(0.004)\end{array}$ & $\begin{array}{c}0.001 * * * \\
(0.000)\end{array}$ & $\begin{array}{c}0.009 \\
(0.008)\end{array}$ & $\begin{array}{c}0.003 * * * \\
(0.001)\end{array}$ & $\begin{array}{c}0.005 \\
(0.008)\end{array}$ & $\begin{array}{l}0.003 * \\
(0.002)\end{array}$ & $\begin{array}{c}0.031 \\
(0.020)\end{array}$ & $\begin{array}{c}0.108 \\
(0.199)\end{array}$ \\
\hline Region $\sim$ Kisangani & $\begin{array}{c}0.004 \\
(0.003)\end{array}$ & $\begin{array}{c}0.000 \\
(0.000)\end{array}$ & $\begin{array}{c}0.001 \\
(0.007)\end{array}$ & $\begin{array}{c}0.003 * * * \\
(0.001)\end{array}$ & $\begin{array}{c}0.003 \\
(0.008)\end{array}$ & $\begin{array}{c}0.007 * * * \\
(0.001)\end{array}$ & $\begin{array}{c}0.026^{* *} \\
(0.012)\end{array}$ & $\begin{array}{l}-0.009 \\
(0.241)\end{array}$ \\
\hline Region $\sim$ Matadi & $\begin{array}{l}-0.000 \\
(0.004)\end{array}$ & $\begin{array}{c}0.000 \\
(0.000)\end{array}$ & $\begin{array}{l}-0.007 \\
(0.005)\end{array}$ & $\begin{array}{c}0.002 * * \\
(0.001)\end{array}$ & $\begin{array}{l}-0.008 \\
(0.009)\end{array}$ & $\begin{array}{c}0.006^{* * * *} \\
(0.001)\end{array}$ & $\begin{array}{c}-0.749 * * * \\
(0.012)\end{array}$ & $\begin{array}{l}{ }^{k}-0.300 \\
(0.244)\end{array}$ \\
\hline Region $\sim$ Kinshasa & ref. & ref. & ref. & ref. & ref. & ref. & ref. & ref. \\
\hline Obs. & 105 & 105 & 105 & 105 & 105 & 105 & 105 & 105 \\
\hline Pseudo R2 & 0.0765 & 0.0035 & 0.0692 & 0.0060 & 0.0787 & 0.0084 & 0.2905 & 0.3146 \\
\hline Efficiency pred. & 0.0142 & 0.0004 & 0.0186 & 0.0013 & 0.0234 & 0.0024 & 0.3926 & 0.5207 \\
\hline
\end{tabular}

Numbers in parentheses are standard deviation and $* p<0.1 ; * * p<0.05 ; * * * p<0.01$

Computed by author from World Bank Enterprise Surveys. 
Table 6. Firms' efficiency determinants (marginal effects from Interquantiles regression: robustness check)

\begin{tabular}{lcccccc}
\hline Explained Variable: Efficiency & \multicolumn{2}{c}{$\Delta \tau_{(.10 ; 20)}$} & \multicolumn{2}{c}{$\Delta \tau_{(.20 ; 30)}$} & \multicolumn{2}{c}{$\Delta \tau_{(.30 ; 95)}$} \\
\cline { 2 - 7 } & 2006 & 2010 & 2006 & 2010 & 2006 & 2010 \\
\hline Hostility Business Environment Index & 0.004 & -0.000 & -0.001 & -0.000 & 0.100 & 0.243 \\
HBEI) & $(0.006)$ & $(0.001)$ & $(0.013)$ & $(0.003)$ & $(0.065)$ & $(0.338)$ \\
Dummy Corruption & 0.001 & 0.000 & -0.006 & 0.000 & $-0.754^{* *}$ & 0.120 \\
& $(0.003)$ & $(0.000)$ & $(0.004)$ & $(0.001)$ & $(0.329)$ & $(0.246)$ \\
Ln(Number of employees) & -0.003 & 0.000 & 0.000 & 0.000 & -0.011 & 0.070 \\
Ln(Firm age) & $(0.002)$ & $(0.000)$ & $(0.002)$ & $(0.001)$ & $(0.016)$ & $(0.076)$ \\
& -0.005 & -0.000 & -0.002 & -0.000 & $-0.080^{* *}$ & $0.272^{* *}$ \\
Dummy Manufacturing & $(0.006)$ & $(0.000)$ & $(0.007)$ & $(0.001)$ & $(0.038)$ & $(0.127)$ \\
Dummy Retail & 0.002 & -0.000 & 0.001 & -0.000 & -0.064 & -0.159 \\
Dummy Services & $(0.003)$ & $(0.000)$ & $(0.008)$ & $(0.001)$ & $(0.255)$ & $(0.280)$ \\
Region Lubumbashi & 0.006 & 0.001 & 0.006 & 0.002 & 0.004 & -0.319 \\
& $(0.007)$ & $(0.001)$ & $(0.013)$ & $(0.002)$ & $(0.473)$ & $(0.275)$ \\
Region $\sim$ Kisangani & ref. & ref. & ref. & ref. & ref. & ref. \\
Region Matadi & $0.012^{* * *}$ & 0.002 & -0.003 & -0.000 & 0.026 & 0.105 \\
Region Kinshasa & $(0.005)$ & $(0.001)$ & $(0.011)$ & $(0.003)$ & $(0.028)$ & $(0.271)$ \\
$N$ & -0.004 & 0.002 & 0.002 & 0.004 & 0.024 & -0.016 \\
\hline & $(0.004)$ & $(0.002)$ & $(0.015)$ & $(0.094)$ & $(0.076)$ & $(0.315)$ \\
& $-0.006^{* *}$ & 0.001 & -0.001 & 0.004 & $-0.741^{* *}$ & -0.306 \\
& $(0.003)$ & $(0.003)$ & $(0.013)$ & $(0.007)$ & $(0.334)$ & $(0.192)$ \\
& ref. & ref. & ref. & ref. & ref. & ref. \\
\hline & 105 & 105 & 105 & 105 & 105 & 105 \\
\hline
\end{tabular}

Numbers in parentheses are standard deviation and $* p<0.1 ; * * p<0.05 ; * * * p<0.01$

Computed by author from World Bank Enterprise Surveys.

The findings from quantiles regression (table 5) show that all the companies do not take advantage of the hostility of the business environment. In reality, only the most successful companies (highest Quantile: Q.95) profit from the increase in hostile business environment. The same firms are also the most involved in corruption practices. Once more, these analyses corroborate previous research (Leff, 2002 and Riley, 2002) on developing countries. An analysis of financial data from more than 9000 companies in 51 countries (Mironov, 2005) delivers similar results: residual corruption is positively correlated with capital accumulation and productivity growth in developing countries.

These empirical findings are consistent with the theory that corruption helps in overcoming inefficient barriers. Finally, the absence of more significant variables in interquantiles regression (table 6) indicates that our previous findings are robust. The Interquantiles distances do not hide significant information in our model.

\section{Conclusion}

The paper aimed to explore the link between business environment and firm efficiency in Democratic Republic of Congo (DRC) in its early the post-conflict period. Using the World Bank Enterprise Survey for 2006 and 2010 waves, the study aimed at determining whether during the considered period there was an improvement of the investment climate and business environment and, how the later affected firm's efficiency.

Based on the 105 firms observed in both waves, our econometric results indicate that five years after the conflict in DRC, the efficiency of firms did not rise significantly. The mean level of efficiency was 0.0725 over a scale spanning from 0 to 1 . This score corresponding to $92.75 \%$ of inefficiency. Over the same period, Hostility Business Environment Index (HBEI) rose from 0.4914 to 0.5765 and this variation was mainly due to the 
complexity of the relationship between business and the government. Finally, the study reveals a positive link between a hostility business environment and firm efficiency. Our findings indicate that the prevailing disorder benefits only to more efficient firms which are able to pay highest bribes and the State seems to be the first loser. Thus, effective policies against corruption practices in DRC would pass through the improvement of investment climate and business environment. Furthermore, given the uncertainties that corruption generates, it is likely to have additional effects on the way private firms do business. The corrupt firm may have a short run orientation. There are two reasons for this. First, firms involved in corruption may fear that those in power are vulnerable to overthrow because of their corruption and, in this case, a new regime may not honor the old one's commitments. Second, even if the current regime remains in power, firms' managers may still fear the imposition of arbitrary rules once investments are sunk. Therefore they are permanently under a threat of seeing their contract voided for political reasons or greed. In fact, having paid a bribe in the past, the firm is vulnerable to any kind of extortion in the future. Finally, the decrease of the level of corruption benefits to both the State and firms. Such a result supports the empirical evidence stating that improvement in education, more political rights and participation (democracy) have a depressing effect on corruption in a country.

Future extensions of the present paper would be oriented in two directions. First, by quantifying the loss that the State's bears due to the hostile business environment. This would highlight political leaders and policy-makers on the necessity of institutional reforms. Second, there is a necessity of focusing on the cost-benefit analysis of corruption with both short and long-run profit being taken into account. Beyond the economic rationality, ethical issues and corporate responsibility could be also discussed as important factors of firm's performance.

\section{Acknowledgements}

The author is grateful to various anonymous reviewers for their comments. Specially, we are grateful to the World Bank Group who proved data for this research (Enterprise Surveys). The findings, interpretations and conclusions expressed in this paper are entirely those of the author.

\section{References}

Agasisti, T., \& Pérez-Esparrells, C. (2010). Comparing efficiency in a crosscountry perspective: the case of Italian and Spanish state universities. Higher Education, 59(1), 85-103. http://dx.doi.org/10.1007/s10734-009-9235-8

Asiedu, E., \& Freeman, J. (2009). The Effect of Corruption on Investment Growth: Evidence from Firms in Latin America, Sub-Saharan Africa, and Transition Countries. Review of Development Economics, 13(2), 200-214. http://dx.doi.org/10.1111/j.1467-9361.2009.00507.x

Azadeh, A., Keramati, A., \& Jafary, S. M. (2009). An integrated Delphi/VAHP/DEA framework for evaluation of information technology/information system (IT/IS) investments. The International Journal of Advanced Manufacturing Technology, 45(11/12), 1233-1251. http://dx.doi.org/10.1007/s00170-009-2047-2

Bardhan, P. (1997). Corruption and Development: A Review of Issues. Journal of Economic Literature, 35(3), 1320-1346.

Baum, J. R., \& Wally, S. (2003). Strategic decision speed and firm performance. Strategic Management Journal, 24(11), 1107-1129. http://dx.doi.org/10.1002/smj.343

Brunetti, A., \& Weder, B. (2003). A free press is bad news for corruption. Journal of Public Economics, 87(7-8), 1801-1824. http://dx.doi.org/10.1016/S0047-2727(01)00186-4

Camanho, A. S., \& Dyson, R. G. (2005). Cost efficiency measurement with price uncertainty: a DEA application to bank branch assessments. European Journal of Operational Research, 161(2), 432-446. http://dx.doi.org/10.1016/j.ejor.2003.07.018

Charnes, A., Cooper, W. W., \& Rhodes, E. L. (1978). Measuring the efficiency of decision making units. European Journal of Operational Research, 2(4), 429-444. http://dx.doi.org/10.1016/0377-2217(78)90138-8

Chen, Y., \& Iqbal Ali, A. (2004). DEA Malmquist productivity measure: New insights with an application to computer industry. European Journal of Operational Research, 159(1), 239-249. http://dx.doi.org/10.1016/S0377-2217(03)00406-5

Cook, W. D., \& Seiford, L. M. (2009). Data envelopment analysis (DEA) -Thirty years on. European Journal of Operational Research, 192(1), 1-17. http://dx.doi.org/10.1016/j.ejor.2008.01.032

Cook, W. D., \& Zhu, J. (2007). Within-group common weights in DEA: An analysis of power plant efficiency. 
European Journal of Operational Research, 178(1), 207-216. http://dx.doi.org/10.1016/j.ejor.2006.01.019

Cooper, W. W., Li, S., Seiford, L. M., Tone, K., Thrall, R. M., \& Zhu, J. (2001). Sensitivity and stability analysis in DEA: Some recent developments. Journal of Productivity Analysis, 15(3), 217-246. http://dx.doi.org/10.1023/A:1011128409257

Cooper, W. W., Ruiz, J. L., \& Sirvent, I. (2009). Selecting non-zero weights to evaluate effectiveness of basketball players with DEA. European Journal of Operational Research, 195(2), 563-574. http://dx.doi.org/10.1016/j.ejor.2008.02.012

Dal Bó, E., \& Rossi, M. A. (2007). Corruption and inefficiency: Theory and evidence from electric utilities. Journal of Public Economics, 91(5-6), 939-962. http://dx.doi.org/10.1016/j.jpubeco.2006.11.005

Deetz, M., Poddig, T., Sidorovitch, I., \& Varmaz, A. (2009). An evaluation of conditional multi-factor models in active asset allocation strategies: an empirical study for the German stock market. Financial Markets and Portfolio Management, 23(3), 285-313. http://dx.doi.org/10.1007/s11408-009-0106-1

Doh, J., \& Teegen, H. (2003). Private Telecommunications Investment in Emerging Economies-Comparing the Latin American and Asian Experience. Management Research, 1(1), 9-26.

Drury, A. C., Krieckhaus, J., \& Lusztig M. (2006). Corruption, Democracy, and Economic Growth. International Political Science Review, 27(2), 121-136. http://dx.doi.org/10.1177/0192512106061423

Edelstein, J. Y. (1992). Adjustment and decline in hostile environments. New York: Garland Publishing.

Eifert, B., Gelb, A., \& Ramachandran, V. (2008). The Cost of Doing Business in Africa: Evidence from

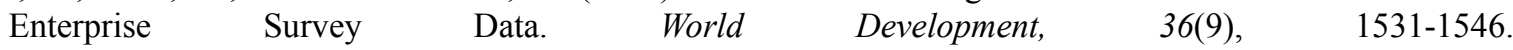
http://dx.doi.org/10.1016/j.worlddev.2007.09.007

Elbanna, S. (2009). The impact of affective conflict on firm performance. Management Research Review, 32(9), 789-803.

Elbanna, S., \& Child, J. (2007). Influences on strategic decision effectiveness: Development and test of an integrative model. Strategic Management Journal, 28(4), 431-453. http://dx.doi.org/10.1002/smj.597

Emerson, P. M. (2006). Corruption, competition and democracy. Journal of Development Economics, 81(1), 193-212. http://dx.doi.org/10.1016/j.jdeveco.2005.04.005

Fosu, A. K., Mlambo, K., \& Oshikoya, T. W. (2001). Business Environment and Investment in Africa: An Overview. Journal of African Economies, 10(2), 1-11. http://dx.doi.org/10.1093/jae/10.Suppl2.1

Goll, I., \& Rasheed, A. A. (1997). Rational decision-making and firm performance: The moderating role of $\begin{array}{llll}\text { environment. Strategic } & \text { Management }\end{array}$ http://dx.doi.org/10.1002/(SICI)1097-0266(199708)18:7<583::AID-SMJ907>3.0.CO;2-Z

Jeffrey, E., \& Michael, J. R. (1997). Responding to increased environmental hostility: a study of the competitive behavior of small retailers. Journal of applied Business Research, 13(1), 83-94.

Ji, Y., \& Lee, C. (2010). Data envelopment analysis. The Stata Journal, 10(2), 267-280.

Kaufmann, D., Kraay, A., \& Mastruzzi, M. (2009). Governance Matters VIII: Aggregate and Individual Governance Indicators 1996-2008. The World Bank, WPS4978.

Kinda, T. (2010). Investment Climate and FDI in Developing Countries: Firm-Level Evidence. World Development, 38(4), 498-513. http://dx.doi.org/10.1016/j.worlddev.2009.12.001

Koenker, R., \& Hallock, K. F. (2001). Quantile Regression. Journal of Economic Perspectives, 15(4), 143-156. http://dx.doi.org/10.1257/jep.15.4.143

Kolenikov, S., \& Angeles, G. (2004). The Use of Discrete Data in Principal Component Analysis With Applications to Socio-Economic Indices. CPC/MEASURE Working paper No.WP-04-85.

Kotha, S., \& Nair, A. (1995). Strategy and environment as determinants of performance: Evidence from the Japanese machine tool industry. Strategic Management Journal, 16(7), 497-518. http://dx.doi.org/10.1002/smj.4250160702

Krishnakumar, J., \& Nagar, A. L. (2008). On exact statistical properties of multidimensional indices based on principal components, factor analysis, MIMIC and structural equation models. Social Indicators Research, 86(3), 481-496. http://dx.doi.org/10.1007/s11205-007-9181-8

Kuah, C. T., Wong, K. Y., \& Behrouzi, F. (2010). A Review on Data Envelopment Analysis (DEA): Asia 
Modelling Symposium. 4th Asia International Conference on Analytical Modelling \& Computer Simulation, Kota Kinabalu, Malaysia.

Leff, N. (2002). Economic development through bureaucratic corruption. In Heidenheimer, A., \& M. Johnson (Eds.), Political Corruption: Concepts and Contexts.

Lonial, S., \& Raju, P. (2001). The impact of environmental uncertainty on the market orientation-performance relationship: A study of the hospital Industry. Journal of Economic and Social Research, 3(1), 5-27.

Mahagaonkar, P. (2008). Corruption and innovation: a grease or sand relationship? Economics Research Paper No. 2008-017, Max Planck Institute of Economics.

Mauro, P. (1995). Corruption and Growth. Quarterly Journal of Economics, 110(3), 681-712. http://dx.doi.org/10.2307/2946696

McArthur, A. W., \& Nystrom, P. C. (1991). Environmental dynamism, complexity and munificence as moderators of strategy-performance relationships. Journal of Business Research, 23(4), 349-361. http://dx.doi.org/10.1016/0148-2963(91)90020-X

Miller, D., \& Friesen, P. H. (1983). Strategy making and environment: The third link. Strategic Management Journal, 4(3), 221-235. http://dx.doi.org/10.1002/smj.4250040304

Mironov, M. (2005). Bad Corruption, Good Corruption and Growth. Working paper. Retrieved from $\mathrm{http} / / /$ home.uchicago.edu/ mmirono1

Morgan, P. M., Danny, R. A., \& Donald, L. T. (1993). The interrelationship between environment hostility and entrepreneurial orientation. Journal of applied Business Research, 9(4), 12-23.

Nagar, A. L., \& Basu, S. R. (2002). Weighting socio-economic indicators of human development: a latent variable approach. In Ullah, et al. (org.), Handbook of applied econometrics and statistical inference. New York: Marcel Dekker, Chap. 29.

Nye, J. S. (1967). Corruption and Political Development: A Cost Benefit Analysis. American Political Science Review, 61(2), 417-27. http://dx.doi.org/10.2307/1953254

Rajagopalan, N., Rasheed, A. M. A., \& Datta, D. K. (1993). Strategic decision processes: Critical review and future directions. Journal of Management, 19(2), 349-385.

Riley, S. (2002). Public Office Corruption in West Africa: Political Culture, Context and Control. In Heidenheimer A., \& M. Johnson (Eds.), Political Corruption: Concepts and Contexts.

Rose-Ackerman, S. (2002). "Grand" corruption and the ethics of global business. Journal of Banking \& Finance, 26(9), 1889-1918. http://dx.doi.org/10.1016/S0378-4266(02)00197-8

Shleifer, A., \& Vishny, R. W. (1993). Corruption. Quarterly Journal of Economics, 108(3), 599-617. http://dx.doi.org/10.2307/2118402

Simar, L., \& Wilson, P. (2007). Estimation and inference in two-stage, semi-parametric models of production processes. Journal of Econometrics, 136(1), 31-64. http://dx.doi.org/10.1016/j.jeconom.2005.07.009

Skeels, C., \& Vella, F. (1997). Monte Carlo evidence on the robustness of conditional moment tests in tobit and probit models. Econometric Reviews, 16(1), 69-92. http://dx.doi.org/10.1080/07474939708800373

Specht, P. H. (1993). Munificence and carrying capacity of the environment and organization formation. Entrepreneurship Theory and Practice, 17(2), 77-86.

Wan, W. P., \& Hoskisson, R. E. (2003). Home country environments, corporate diversification strategies, and firm performance. Academy of Management Journal, 40(1), 27-45. http://dx.doi.org/10.2307/30040674

Wang, S., Ran, G., Wang, L., \& Shi, B. (2009). An evaluation on performance of rural eco-environment public expenditure of Chinese local governments: theoretical and empirical analysis. Frontiers of Earth Science in China, 3(4), 431-436. http://dx.doi.org/10.1007/s11707-009-0059-8

Wong, W. P., \& Wong, K. Y. (2007). Supply chain performance measurement system using DEA modeling. Industrial Management \& Data Systems, 107(3), 361-381. http://dx.doi.org/10.1108/02635570710734271

Yu, M. M., \& Chen, P. C. (2009). Measuring air routes performance using a fractional network data envelopment analysis model. Central European Journal of Operations Research, 19(1), 81-98. http://dx.doi.org/10.1007/s10100-009-0131-1

Zahra, S. A., Neubaum, D. O., \& Huse, M. (1997). The effect of the environment on export performance among 
telecommunications new ventures. Entrepreneurship Theory and Practice, 22(1), 25-46.

\section{Notes}

Note 1 . The gain may accrue to an individual or a group, or to those closely associated with such an individual or group.

Note 2. DRC is one of sub-Saharan countries which suffered very much from civil war and violent protests. In spite of important endowment in natural resources considered as a significant potentiality for local and foreign investors, instability of institutions and investment climate continue to constraint doing business.

Note 3. Regulatory Quality (RQ) is one of the six dimensions of governance score (Voice and Accountability, Political Stability and Absence of Violence/Terrorism, Government Effectiveness, Regulatory Quality, Rule of Law, and Control of Corruption). RQ captures perceptions of the ability of the government to formulate and implement sound policies and regulations that permit and promote private sector development.

Note 4. See www.enterprisesurveys.org for the detailed description of the data and methodology used in sampling.

\section{Appendix}

Appendix 1. Correlation matrix table

\begin{tabular}{lllllllllllll}
\hline & $(1)$ & $(2)$ & $(3)$ & $(4)$ & $(5)$ & $(6)$ & $(7)$ & $(8)$ & $(9)$ & $(10)$ & $(11)$ & $(12)$ \\
\hline$(1)=$ efficiency & 1.00 & & & & & & & & & & & \\
$(2)=$ HBEI & $0.14^{*}$ & 1.00 & & & & & & & & & & \\
$(3)=$ Corruption & -0.05 & -0.07 & 1.00 & & & & & & & & & \\
$(4)=$ Employees & -0.02 & 0.02 & -0.02 & 1.00 & & & & & & & & \\
$(5)=$ Firm age & -0.08 & 0.07 & 0.04 & $0.19^{*}$ & 1.00 & & & & & & & \\
$(6)=$ Manufacturing & $-0.17 *$ & 0.04 & -0.03 & $0.25^{*}$ & -0.06 & 1.00 & & & & & & \\
$(7)=$ Retail & 0.06 & 0.01 & -0.08 & $-0.19^{*}$ & -0.01 & $-0.50^{*}$ & 1.00 & & & & & \\
$(8)=$ Services & $0.14^{*}$ & -0.05 & 0.10 & -0.12 & 0.07 & $-0.69^{*}-0.29 *$ & 1.00 & & & & \\
$(9)=$ Kinshasa & 0.01 & 0.12 & 0.12 & $0.17^{*}$ & 0.02 & -0.05 & -0.01 & 0.07 & 1.00 & & & \\
$(10)=$ Lubumbashi & -0.06 & $-0.38^{*}$ & 0.05 & 0.00 & -0.07 & 0.03 & -0.03 & -0.01 & $-0.54^{*}$ & 1.00 & & \\
$(11)=$ Kisangani & 0.07 & 0.12 & -0.00 & -0.06 & 0.01 & 0.02 & 0.03 & -0.04 & $-0.52^{*}$ & -0.07 & 1.00 & \\
$(12)=$ Matadi & -0.03 & 0.09 & $-0.24^{*}$ & $-0.21^{*}$ & 0.03 & 0.03 & 0.02 & -0.05 & $-0.54^{*}$ & -0.08 & -0.07 & 1.00 \\
\hline
\end{tabular}

* Significant at 5\%.

Appendix 2. Detection of collinearity of the regressors (VIF test)

\begin{tabular}{lll}
\hline Variable & VIF & $1 /$ VIF \\
\hline Manufacturing & 1.41 & 0.708111 \\
Retail & 1.35 & 0.738661 \\
Employees & 1.21 & 0.829421 \\
HBEI & 1.19 & 0.840309 \\
Lubumbashi & 1.18 & 0.848401 \\
Matadi & 1.16 & 0.865055 \\
Corruption & 1.09 & 0.918122 \\
Firm age & 1.07 & 0.935961 \\
Kisangani & 1.03 & 0.969928 \\
Mean VIF & 1.19 & 0.850441 \\
\hline
\end{tabular}


Appendix 3. Skewness/Kurtosis tests for Normality

\begin{tabular}{lccccc}
\hline Variable & Obs & $\operatorname{Pr}($ Skewness) & $\operatorname{Pr}$ (Kurtosis) & adj chi2(2) & Prob $>$ chi2 \\
\hline Efficiency & 210 & 0.0000 & 0.0000 &. & 0.0000 \\
HBEI & 210 & 0.0220 & 0.3175 & 6.07 & 0.0482 \\
Corruption & 210 & 0.9073 &. &. &. \\
Employees & 210 & 0.0000 & 0.0666 & 23.50 & 0.0000 \\
Firm age & 210 & 0.2952 & 0.3182 & 2.11 & 0.3476 \\
Manufacturing & 210 & 0.2962 &. &. &. \\
Retail & 210 & 0.0000 & 0.0138 & 48.54 & 0.0000 \\
Services & 210 & 0.0000 & 0.0000 & 61.66 & 0.0000 \\
Kinshasa & 210 & 0.0000 & 0.7265 & 34.92 & 0.0000 \\
Lubumbashi & 210 & 0.0000 & 0.0000 &. & 0.0000 \\
Kisangani & 210 & 0.0000 & 0.0000 &. & 0.0000 \\
Matadi & 210 & 0.0000 & 0.0000 &. & 0.0000 \\
\hline
\end{tabular}

Appendix 4. Cameron \& Trivedi's decomposition of IM-test and Ramsey RESET test

\begin{tabular}{lccc}
\hline Source & chi2 & df & $\mathrm{p}$ \\
\hline Heteroskedasticity & 38.96 & 44 & 0.6871 \\
Skewness & 16.60 & 9 & 0.0554 \\
Kurtosis & 6.20 & 1 & 0.0128 \\
Total & 61.76 & 54 & 0.2186 \\
\hline Ramsey RESET test using powers of the fitted values & 7.29 & $(3 ; 197)$ & 0.0001 \\
of Efficiency (Ho: model has no omitted variables) & & & \\
\hline
\end{tabular}

